\title{
Forage quality of 10 Eastern gamagrass [Tripsacum dacty- loides (L.) L.] genotypes
}

\author{
JAMES E. BIDLACK, JOE E. VAUGHAN, AND C. L. DEWALD
}

Authors are associate and assistant emeritus professors, Department of Biology, University of Central Oklahoma, Edmond, Okla. 73034; and research agronomist, U.S. Department of Agriculture, Agricultural Research Service, Southern Plains Range Research Station, 2000 18th Street, Woodward, Oklahoma 73801 .

\section{Abstract}

Ten eastern gamagrass [Tripsacum dactyloides (L.) L.] entries from Kansas, Oklahoma, and Texas, were evaluated for in vitro dry matter digestibility (IVDMD), protein concentration, lignin concentration, and phenylalanine ammonia lyase (PAL) activity. Whole plants were harvested in Spring 1992 and 1995 from 4 replicates of each entry and divided into leaf and stem (plus sheath) components for analyses. Entry significantly affected all measurements except PAL; whereas the entry by year interaction significantly affected stem IVDMD, protein, and PAL. Across entries, stem IVDMD in $1992(56.3 \%$ to $66.4 \%)$ and $1995(55.9 \%$ to $64.9 \%$ ) demonstrated greater variation than leaf IVDMD in $1992(62.2 \%$ to $68.0 \%)$ and $1995(66.7 \%$ to $71.0 \%)$. In 1992 and 1995, average leaf IVDMD and protein concentration were generally higher than average stem IVDMD and protein concentration. In 1992, lignin concentration was generally higher and varied more in stems $(3.27 \%$ to $4.99 \%)$ than in leaves $(3.54 \%$ to $4.11 \%)$. In 1995 , lignin concentration was about the same and varied more in leaves compared with stems. Stem IVDMD was significantly correlated with lignin concentration in $1992(r=-0.92)$ and $1995(r=-0.83)$ as well as with protein concentration $(r=0.83)$ in 1995. Activity of PAL in 1995 was correlated with stem IVDMD and protein. When all data were combined, IVDMD was significantly correlated with protein concentration $(r=0.82)$. These results indicate that gamagrass entries demonstrate significant variation in forage quality, particularly in stems. Potential exists for development of new gamagrass cultivars with high IVDMD and protein.

Key Words: digestibility, gamagrass, forage, lignin, phenylalanine ammonia lyase, protein, Tripsacum dactyloids, quality

All programs and services of the U.S. Department of Agriculture are offered on a non-discriminatory basis without regard to race, color, national origin, religion, sex, age, marital status, or handicap.

Research funded in part by the University of Central Oklahoma Office of Faculty Research and the USDA-ARS Southern Plains Range Research Station. Authors wish to thank Jerry McLaughlin, ARS, for performing IVDMD, protein, and fiber analyses and extend appreciation to Carrie Barton and Travis Swink for assisting with enzyme analyses and data entry.

Manuscript accepted 23 Jan. 1999

\section{Resumen}

Se evalúo la calidad de forraje de $\mathbf{1 0}$ genotipos de "Eastern Gamagrass" (Tripsacum dactyloides (L.) L.) provenientes de Kansas, Oklahoma y Texas. Se determinó la digestibilidad in vitro de la materia seca (DIVMS), la concentración de proteína y lignina y la actividad de fenilalanina amonia liasa (PAL). En la primavera de 1992 y 1995 se cosecharon plantas enteras en 4 repeticiones de cada genotipo, para su análisis se separaron en hojas y tallos (mas la vaina). Hubo diferencias significativas por efecto de genotipo en todas las variables excepto el PAL, la interacción genotipo por año afectó significativamente la DIVMS de tallos, proteína y PAL. Entre genotipos, la DIVMS de tallos, en 1992 (56.3\% a $66.4 \%)$ y $1995(55.9 \%$ a $64.9 \%)$, mostró mayor variabilidad que la DIVMS de hojas $(62.2 \%$ a $68.0 \%$ en 1992 y $66.7 \%$ a $71.0 \%$ en 1995). En 1992 y 1995, los promedios de la DIVMS y la concentración de proteína de las hojas fueron generalmente más altos que los promedios de los tallos. En 1992, la concentración de lignina fue generalmente más alta y más variable en tallos $(3.27 \%$ a $4.99 \%)$ que en hojas $(3.54 \%$ a $4.11 \%)$. En 1995, la concentración de lignina fue aproximadamente la misma y varió más en hojas que en tallos. La DIVMS de tallos se correlaciono significativamente con la concentración de lignina $(r=-0.92$ en 1992 y $r=-0.83$ en 1995) y con la concentración de proteína $(r=0.83$ en 1995). En 1995, La actividad de PAL se correlaciono con la DIVMS y la concentración de proteína de los tallos. Cuando se combinaron todos los datos, la DIVMS se correlaciono significativamente con la concentración de proteína $(r=0.82)$. Estos resultados indican que los genotipos de "Gamagrass" tienen una variación significativa en cuanto a calidad de forraje, particularmente los tallos. Existe el potencial para desarrollar nuevos cultivares de "Gamagrass" con altos contenidos de proteína y alta DIVMS.

The new world grass genera, Tripsacum and Zea are phylogenetically allied with the subtribe Tripsacinae of the Andropogoneae tribe of the family Poaceae (Clayton 1973, de Wet and Harlan 1978). Brink and de Wet (1983) recognized 16 species of Tripsacum, with eastern gamagrass [Tripsacum dactyloides (L.) L.] being the most widespread and morphologically variable species. Eastern gamagrass can be found from Massachusetts to Nebraska in the USA ( $42^{\circ} \mathrm{N}$ Lat.) and southward sporadically through Meso America and into upper 
South America (24 S Lat.). The western escarpment of central Mexico is cited as the center of Tripsacum diversity (Wilkes 1972).

Eastern gamagrass has been recognized as a highly productive and palatable forage of the eastern prairies (Rechenthin 1951). Previous work has demonstrated the productive superiority of eastern gamagrass compared with other grasses of the central and south central USA (Faix et al. 1980, Sims 1985, Vogel et al. 1985), as well as its unique morphological and reproductive traits (Dewald and Louthan 1979, Dewald et al. 1987). Evaluation of gamagrass germplasm showed a considerable range in yield, forage quality, and seed production (Wright et al. 1983, Kenna 1984). There is limited information on genotype and plant part variation in eastern gamagrass forage quality and metabolism. Knowledge of genotypic differences in forage quality is required for plant breeders to develop improved cultivars.

Ten eastern gamagrass entries from Oklahoma, Texas, and Kansas, and their progeny from specific crosses, were investigated as an observational study, to determine variation in in vitro dry matter digestibility (IVDMD) and protein concentrations. Lignin was studied because of its reported correlation with digestibility (Harkin 1973, Jung and Deety 1993) and the activity of phenylalanine ammonia lyase (PAL) was determined because of its relationship with lignin biosynthesis (Bidlack et al. 1995, Bidlack et al. 1997). The objectives were to determine: 1) if the variation in digestibility among different entries of eastern gamagrass was sufficient for the development of cultivars with improved quality, and 2) whether or not genetic variation in IVDMD is related to differences in protein and lignin concentration and PAL activity.

\section{Materials and Methods}

Eastern gamagrass entries were selected for visual diversity, persistence, and uniformity among replicates from a field nursery established vegetatively in April 1991 at Woodward, Okla. Plants were arranged in a randomized complete block design with 4 replicates and irrigated and fertilized with nitrogen as necessary. The selected entries included
4 parents: 1023, from Nowata, Okla.; 1218 from Flush, Kan.; 1379 from Texarkana, Tex.; and 1582 from Ottawa County, Kan,. A plant of unknown origin (OP) and the 4 parents were used to produce 4 progeny: 1673 (1023 X OP), 1748 (1582 X 1218), 1759 (1582 X 1379), and 1760 (1582 X 1,379). Plants from the $F_{1}$ generation were used to produce the 2 remaining entries, 1792 (1673 X 1760) and 1793 (from another 1673 X 1760). Each plant crown originally contained 30 to 200 vegetative shoots which remained vegetative or became reproductive tillers in the spring of subsequent years.

Reproductive tillers from each crown were sampled on 14 May 1992 and 1 June 1995. Stage of plant development at harvest, according to Simon and Park (1983), ranged from 52 (25\% of inflorescence emerged) to 56 (75\% of inflorescence emerged) in 1992 and from 56 to 62 (beginning of anthesis) in 1995. Fifty to $100 \mathrm{~g}$ of fresh weight (FW) tillers were removed by cutting to a 5.0 $\mathrm{cm}$ stubble. Tissue was transported, within 15 minutes of cutting, and divided into leaf, and stem plus sheath components. Since sheaths were included with stem samples, the word "stem" should hereafter be interpreted as including both stem and sheath.

A subsample of the fresh leaf and stem tissue was used for PAL assays. The remaining material was weighed, placed in a paper bag, dried at $55^{\circ} \mathrm{C}$ for 48 hours, ground in a mill to pass a 1 $\mathrm{mm}$ screen, and used for analyses.

\section{Digestibility, Protein, and Lignin Determination}

In vitro dry matter digestibility was determined by the 2 -stage direct acidification method described by Marten and Barnes (1980). Rumen fluid was collected from a fistulated steer fed on a native grass diet supplemented with an alfalfacotton seed mix. Duplicate samples from each experimental unit were hydrated in buffer for at least 1 hour before inoculation. Calculation of IVDMD was based on dry matter disappearance after 48 hours of fermentation followed by acid pepsin digestion for 24 hours.

Kjeldahl nitrogen concentration (Bremner and Breitenbeck 1983) was multiplied by 6.25 to estimate crude protein. Sequential fiber analysis out- lined by Van Soest and Robertson (1980) was used to determine levels of lignin and other cell wall (CW) components in the ground stem samples. Lignin was calculated as the acid detergent lignin residue isolated from a $72 \%$ $\mathrm{H}_{2} \mathrm{SO}_{4}$ extraction minus ash weight.

\section{Enzyme Extraction and Assay}

Acetone powders of plant material were prepared to avoid enol tautomerborate complexes associated with direct aqueous extracts (Erez 1973). Approximately $3.0 \mathrm{~g}$ of fresh plant material was homogenized in acetone $\left(-78^{\circ} \mathrm{C}, 200 \mathrm{ml}\right)$ with a blender for 2 min. An acetone powder was collected from the homogenate by Büchner filtration through Whatman ${ }^{1}$ No. 54 filter paper and rinsed with $50 \mathrm{ml}$ of cold acetone. After air-drying for 1 hour, the powder was stored in an ultra-low freezer at $-70^{\circ} \mathrm{C}$.

Complete replicates were removed from the freezer and $25 \mathrm{mg}$ of acetone powder from individual samples was mixed with $25 \mathrm{ml}$ of $100 \mathrm{mM}$ borate buffer, $\mathrm{pH} 8.7$, at 0 to $2^{\circ} \mathrm{C}$. Suspensions were shaken at least once every $5 \mathrm{~min}$ for 1 hour and then filtered through Whatman No. 54 filter paper to give a clear, crude enzyme extract. These extracts contained PAL associated with the endoplasmic reticulum, which is known to be involved with lignin biosynthesis (Wagner and Hrazdina 1984). Duplicate measurements of protein were determined for these extracts (Bradford 1976) to enable expression of PAL on a per unit protein basis.

The PAL enzyme was assayed spectrophotometrically from a mixture of 1.5 $\mathrm{ml}$ of extract and $4.5 \mathrm{ml}$ of $6.68 \mathrm{mM}$ phenylalanine in borate buffer $(\mathrm{pH}=8.7)$ over a period of 1 hour at $30^{\circ} \mathrm{C}$ in duplicate. Concentration of phenylalanine in the assay mixture was $5.01 \mathrm{mM}$. Enzyme activity (Bidlack et al. 1995) was obtained by measuring production of cinnamic acid at $290 \mathrm{~nm}$ using a molar extinction coefficient of $9000 \mathrm{~cm}^{-1}$ (Saunders and McClure 1974). One unit of activity was expressed as the amount of cinnamic acid produced in micromoles per hour.

\footnotetext{
Mention of a trademark, proprietary product, or vendor does not constitute a guarantee or warranty of the product by the USDA or University of Central Oklahoma and does not imply its approval to the exclusion of other products or vendors that may be suitable.
} 
Table 1. Significance of mean squares for maturity, in vitro dry matter digestibility (IVDMD), crude protein, lignin, and phenylalanine ammonia lyase (PAL) activity of eastern gamagrass established in Spring 1991 and harvested in Spring 1992 and 1995.

\begin{tabular}{|c|c|c|c|c|c|c|c|c|c|c|}
\hline \multirow[b]{2}{*}{ Source } & \multirow[b]{2}{*}{$\mathrm{df}$} & \multirow[b]{2}{*}{ Maturity } & \multicolumn{4}{|c|}{ Leaves } & \multicolumn{4}{|c|}{ Stems } \\
\hline & & & IVDMD & Protein & Lignin & $\overline{\text { PAL }}$ & IVDMD & Protein & Lignin & $\overline{\mathrm{PAL}}$ \\
\hline$\overline{\text { Entry (E) }}$ & 9 & NS & ** & $* *$ & NS & NS & $* *$ & $* *$ & $* *$ & NS \\
\hline Rep & 3 & NS & $* *$ & $* *$ & $*$ & NS & NS & NS & $*$ & NS \\
\hline Error a & 27 & & & & & & & & & \\
\hline Year (Y) & 1 & $* *$ & $* *$ & NS & $* *$ & NS & $* *$ & $* *$ & $* *$ & NS \\
\hline$E * Y$ & 9 & NS & NS & NS & NS & NS & $* *$ & $* *$ & NS & $*$ \\
\hline Error b & 30 & & & & & & & & & \\
\hline
\end{tabular}

*,**Significant at the 0.05 and 0.01 levels of probability, respectively.

$\mathrm{NS}=$ non-significant at the 0.05 level of probability.

\section{Statistical Analyses}

Analysis of variance (ANOVA) was used to determine differences among entries, years, and the entry by year interaction. Entry was analyzed as the main effect whereas year and the entry by year interaction were tested against residual error. Statistical analyses were performed by the general linear model procedure in SAS (SAS PROC GLM, SAS Institute 1985). In cases where differences were significant $(\mathrm{P}<0.05)$, correlations (SAS PROC CORR; SAS Institute 1985) were determined.

\section{Results and Discussion}

Stage of plant development, denoted as maturity in Table 1, did not vary as a result of the entry or entry by year interaction in leaves or stems. This suggested that differences in other plant measurements were attributable to entry, year, or the entry by year interaction, as indicated by the analysis of variance.
Different gamagrass entries significantly affected concentrations of IVDMD and protein in leaves and stems as well as lignin concentration in stems. Year significantly affected all measurements except leaf protein concentration and PAL activity of leaves and stems. Activity of PAL was not altered by entry or year and averaged 170 (leaf) and 266 (stem) $\mu \mathrm{mol} / \mathrm{g} /$ hour in 1992 and 182 (leaf) and 242 (stem) $\mu \mathrm{mol} / \mathrm{g} / \mathrm{h}$ in 1995 (data not shown). The entry by year interaction did not affect any leaf measurements but caused significant differences in all measurements except stem lignin concentration. Unique levels of significance for stems and leaves, coupled with significant differences as affected by years, justified presentation of results for plant parts within each year (Table 2).

Although maturity of gamagrass entries did not vary significantly within years, plants generally averaged the $50 \%$ of inflorescence emerged stage, denoted as "54" in 1992; and the preanthesis stage, denoted as "60," in 1995 (Simon and Park 1983). This was not surprising since the plants were harvested on 14 May in 1992 and 1 June in 1995.

Average leaf IVDMD in 1992 (64.8\%) was lower than leaf IVDMD in $1995(68.8 \%)$, whereas stem IVDMD in $1992(60.4 \%)$ did not differ from stem IVDMD in $1995(58.9 \%)$. Average leaf protein was about the same in 1992 $(19.0 \%)$ and $1995(18.6 \%)$ as was the case for stem protein in $1992(8.2 \%)$ and $1995(7.7 \%)$. Other studies reported that average digestibility of whole-plant eastern gamagrass harvested in September ranged from 47 to $56 \%$ and average crude protein was constant at about $11 \%$ (Faix et al. 1980). High leaf forage quality, as indicated by high leaf IVDMD, has been shown in other perennial grasses (Buxton and Marten 1989), and the superior quality of leaves compared with stems may also be influenced by the location in which the part is found (Hacker and Minson 1981, Smith and Nelson 1985, Buxton and Marten 1989).

Across entries, stem IVDMD in 1992 (56.3\% to $66.4 \%)$ and 1995 (55.9\% to

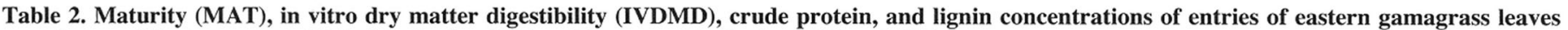
and stems. Plants were established in Spring 1991 and harvested in Spring 1992 and 1995.

\begin{tabular}{|c|c|c|c|c|c|c|c|c|c|c|c|c|c|c|}
\hline & \multirow[b]{3}{*}{ MAT } & \multicolumn{6}{|c|}{14 May 1992} & \multirow[b]{3}{*}{ MAT } & \multicolumn{6}{|c|}{ 1 June 1995} \\
\hline & & \multicolumn{3}{|c|}{ Leaves } & \multicolumn{3}{|c|}{ Stems } & & \multicolumn{3}{|c|}{ Leaves } & \multicolumn{3}{|c|}{ Stems } \\
\hline & & IVDMD & Protein & Lignin & IVDMD & Protein & Lignin & & IVDMD & Protein & $\overline{\text { Lignin }}$ & IVDMD & Protein & Lignin \\
\hline Entry & & $-\cdots$ & $\cdots$ & $\cdots \cdots$ & )$\cdots$ & $\ldots \ldots$ & 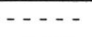 & & $\ldots \ldots$ & $\ldots \ldots$ & $\cdots-($ & )$-\ldots$ & $\ldots \ldots$ & $\ldots \ldots$ \\
\hline 1793 & 53.2 & 68.0 & 20.4 & 3.79 & 66.4 & 8.3 & 3.27 & 61.0 & 71.0 & 20.3 & 6.13 & 63.4 & 8.1 & 4.49 \\
\hline 1759 & 53.5 & 64.7 & 17.9 & 4.02 & 62.6 & 7.6 & 3.42 & 61.0 & 69.1 & 18.7 & 5.08 & 60.1 & 8.0 & 5.78 \\
\hline 1792 & 53.5 & 65.5 & 20.4 & 4.11 & 62.4 & 8.7 & 3.84 & 60.0 & 68.6 & 19.2 & 5.49 & 58.1 & 7.3 & 5.75 \\
\hline 1379 & 55.8 & 65.0 & 18.5 & 3.96 & 61.0 & 7.5 & 4.24 & 61.5 & 70.0 & 18.2 & 6.17 & 57.0 & 6.7 & 6.01 \\
\hline 1582 & 55.3 & 64.2 & 20.3 & 3.55 & 61.8 & 8.4 & 4.19 & 56.5 & 67.7 & 18.3 & - & 64.9 & 9.4 & 5.17 \\
\hline 1760 & 54.2 & 65.4 & 19.0 & 3.74 & 56.5 & 8.4 & 4.85 & 61.5 & 70.0 & 18.2 & 5.89 & 55.9 & 7.1 & 6.54 \\
\hline 1023 & 54.5 & 64.6 & 19.5 & 3.79 & 56.3 & 8.0 & 4.99 & 58.0 & 67.9 & 19.0 & 5.56 & 58.1 & 8.0 & 5.65 \\
\hline 1673 & 56.5 & 64.7 & 19.1 & 3.84 & 60.0 & 9.0 & 4.07 & 59.5 & 66.7 & 18.3 & 5.02 & 57.3 & 8.0 & 6.29 \\
\hline 1218 & 54.0 & 64.3 & 16.9 & 3.72 & 58.8 & 7.4 & 4.34 & 60.0 & 69.1 & 17.3 & 7.57 & 56.8 & 7.3 & 6.05 \\
\hline 1748 & 54.8 & 62.2 & 17.8 & 3.54 & 58.2 & 8.2 & 4.25 & 58.5 & 67.7 & 18.3 & 5.73 & 57.6 & 7.4 & 6.70 \\
\hline Mean & 54.5 & 64.8 & 19.0 & 3.81 & 60.4 & 8.2 & 4.15 & 59.8 & 68.8 & 18.6 & 5.85 & 58.9 & 7.7 & 5.84 \\
\hline $\mathrm{LSD}_{0.05}$ & 3.1 & 1.7 & 1.2 & 0.51 & 2.4 & 0.9 & 0.61 & 3.8 & 1.6 & 1.4 & 2.24 & 2.3 & 0.7 & 0.98 \\
\hline
\end{tabular}




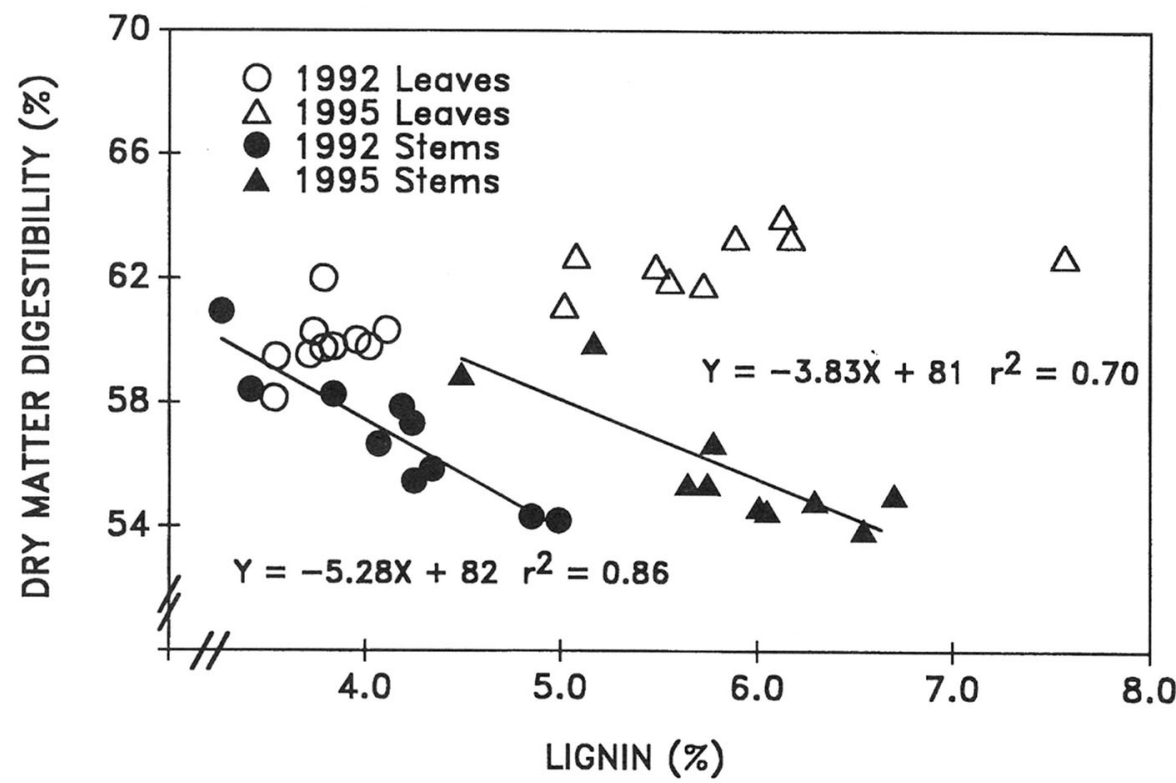

Fig. 1. Relationship between in vitro dry matter digestibility and lignin concentration of 10 lines of eastern gamagrass grown in the field at Woodward, Okla. Plants were established vegetatively in Spring 1991 and harvested in Spring 1992 and 1995. Each point represents the mean of 4 values

$64.9 \%)$ demonstrated greater variation than leaf IVDMD in $1992(62.2 \%$ to $68.0 \%)$ and $1995(66.7 \%$ to $71.0 \%)$ (Table 2). Previous studies have shown that there is greater genetic variation in digestibility of stems compared with leaves of grasses (Hides et al. 1983, Ugherughe 1986, Buxton and Marten 1989). In 1992 and 1995, average leaf IVDMD $(64.8 \%$ and $68.8 \%)$ and protein concentration $(19.0 \%$ and $18.6 \%)$ were generally higher than average stem IVDMD (60.4\% and 58.9\%) and protein concentration $(8.2 \%$ and $7.7 \%)$. These results concur with previous research and indicate that eastern gamagrass demonstrates wider variation in stem IVDMD than in leaves.

Differences in stem lignin concentration for entry (Table 1) suggested that lignin concentration may have affected digestibility of gamagrass genotypes. In 1992, lignin concentration was generally higher and varied more in stems $(3.27 \%$ to $4.99 \%)$ than in leaves $(3.54 \%$ to $4.11 \%$ ) (Table 2). In 1995, lignin concentration was about the same between plant parts and varied more in leaves (5.08\% to $7.57 \%$ ) compared with stems $(5.17 \%$ to $6.70 \%)$.

Relative ranking of gamagrass entries generally exhibited consistency in IVDMD, protein, and lignin concentrations between years and plant parts as high as that of 1793 and 1792 in 1995 . This may have resulted from natural variation in the field. For most entries, consistencies among IVDMD, protein and lignin concentrations were reliable in assessing forage quality even though occasional variation was encountered.

The relationship between lignin and IVDMD was negative and significant ( $\mathrm{r}$ $=-0.92,1992$ and $\mathrm{r}=-0.83,1995 ; \mathrm{P}<$ 0.01 ) for stems, but not for leaves. Stem IVDMD was reduced $5.3\left(\mathrm{r}^{2}=0.86\right)$ and $3.8\left(r^{2}=0.70\right)$ percent for each percentage increase in stem lignin concentration in 1992 and 1995, respectively (Fig. 1). Natural variation in lignin concentration and phenolic composition of plants (Grand et al. 1982, Bidlack and Buxton 1992) has provided incentive to breed for decreased lignin concentration and increased digestibility (Kephart et al. 1990). Other investigations have exploited large variation in measurements of forage stems for digestibility (Buxton and Russell 1988) and cell wall deposition (Bidlack and Buxton 1992) studies. High variation in IVDMD of gamagrass stems and strong negative correlations between IVDMD and lignin suggest that the best approach for improvement of eastern gamagrass forage quality is through selection for high IVDMD and low lignin genotypes.

In 1995, stem IVDMD was positively correlated with protein $(r=0.83$, $\mathrm{P}<0.01)$. Regression analysis showed a 3.3 percentage unit increase in IVDMD for each unit increase in protein. Activity of PAL in 1995 was correlated with stem IVDMD $(\mathrm{r}=0.81, \mathrm{P}<0.01)$ and stem protein $(r=0.66, P<0.05)$. The combined data set demonstrated a positive correlation between IVDMD and protein $(r=0.82, P<0.01)$. These results indicate that eastern gamagrass entries with higher protein concentrations were generally more digestible than gamagrass entries with lower protein concentrations. The positive correlation between PAL activity and stem protein was not surprising since the PAL enzyme is a protein. However, the anticipated relationship between PAL and lignin concentration was not revealed in this experiment; perhaps because it is the amount, as well as the activity of the PAL enzyme, that determines the extent of lignification (Bidlack et al. 1995, Bidlack et al. 1997). Other investigations suggest that, while PAL may initiate the lignification process, 
cinnamyl alcohol:NADPH dehydrogenase activity (Morrison and Buxton 1993) and syringaldazine oxidase activity (Bidlack et al. 1997) are more directly correlated with lignin concentration in stem tissues.

\section{Literature Cited}

Bidlack, J.E. and D.R. Buxton. 1992. Content and deposition rates of cellulose, hemicellulose, and lignin during regrowth of forage grasses and legumes. Can J. Plant Sci. 72:809-818.

Bidlack, J.E., D.R. Buxton, R.M. Shibles, and I.C. Anderson. 1995. Phenylalanine ammonia lyase as a precursory enzyme of legume stem lignification. Can J. Plant Sci. 75:135-140.

Bidlack, J.E., D.R. Buxton, R.M. Shibles, and I.C. Anderson. 1997. Phenylalanine ammonia lyase and syringaldazine oxidase activities in relation to lignin deposition in legumes. Recent Res. Devel. Agron. $1: 1-8$.

Bradford, M.M. 1976. A rapid and sensitive method for the quantitation of microgram quantities of protein utilizing the principle of protein-dye binding. Anal. Biochem. $72: 248-254$

Bremner, J.M. and G.A. Breitenbeck. 1983. A simple method for determination of ammonia in semimicro-Kjeldahl analysis of soils and plant materials using a block digester. Commun. Soil Sci. Plant Anal. 14:905-913.

Brink, D. and J.M. de Wet. 1983. Supraspecific groups in Tripsacum (Gramineae). Syst. Bot. 8:243-249.

Buxton, D.R. and G.C. Marten. 1989. Forage quality of plant parts of perennial grasses and relationship to phenology. Crop Sci. 29:429-435.

Buxton, D.R. and J.R. Russell. 1988. Lignin constituents and cell-wall digestibility of grass and legume stems. Crop Sci. 28:553-558.

Clayton, W.D. 1973. The awnless genera of the Andropogoneae. Kew Bull. 28:49-58.

Dewald, C.L. and V.H. Louthan. 1979. Sequential developments of shoot system components in eastern gamagrass Tripsacum dactyloides (L.) L. J. Range Manage. 32:147-151.

Dewald, C.L., B.L. Burson, J.M.J. de Wet, and J.R. Harlan. 1987. Morphology, inheritance, and evolutionary significance of sex reversal in Tripsacum dactyloides (Poaceae). Amer. J. Bot. 74:1055-1059.

de Wet, J.M.J. and J.R. Harlan. 1978. Tripsacum and the origins of maize. Maize Breeding and Genetics. p. 129-140. John Wiley and Sons, Inc, New York, NY.
Erez, A. 1973. Possible errors in quantitative determination of phenylalanine ammonialyase activity by spectrophotometric methods. Plant Physiol. 51:409-411.

Faix, J.J., C.J. Kaiser, and F.C. Hinds. 1980. Quality, yield, and survival of asiatic bluestems and an eastern gamagrass in southern Illinois. J. Range Manage. 33:388-390.

Grand, C., A.M. Boudet, and R. Ranjeva. 1982. Natural variations and controlled changes in lignification process Holzforschung 36:217-223.

Hacker, J.B., and D.J. Minson. 1981. The digestibility of plant parts. Herb. Abstr. 51:459-482.

Harkin, J.M. 1973. Lignin. p. 323-373. In: G.W. Butler and R.W. Baily (ed.). Chemistry and biochemistry of herbage. Academic Press. New York, N.Y.

Hides, D.H., J.A. Lovatt, and M.V. Hayward. 1983. Influence of stage of maturity on the nutritive value of Italian ryegrass. Grass Forage Sci. 38:33-38.

Jung, H.G. and D.A. Deety. 1993. Cell wall lignification and degradability. $\mathrm{p}$. 315-346. In: H.G. Jung, D.R. Buxton, R.D. Hatfield, and J. Ralph (ed.). Forage cell wall structure and digestibility. Amer. Soc. of Agron., Madison, Wisc.

Kenna, M.P. 1984. Heritability estimates and inbreeding effects for selected agronomic characters in eastern gamagrass Tripsacum dactyloides (L.) L. Ph.D. Dissertation, Oklahoma State Univ., Stillwater, Okla.

Kephart, K.D., D.R. Buxton, and R.R. Hill. 1990. Digestibility and cell-wall components of alfalfa following selection for divergent herbage lignin concentration. Crop Sci. 30:207-212.

Marten, G.C. and R.F Barnes. 1980. Prediction of energy digestibility of forages in vitro rumen fermentation and fungal enzyme systems. p. 61-71. In: W.J. Pigden, C.C. Balch, and M. Graham M (ed.). Proc Int Workshop on Standardization Anal Method Feed. Ottawa, Canada, 12-14 Mar. 1979. Unipub, N.Y.

Morrison, T.A., and Buxton, D.R. 1993. Activity of phenylalanine ammonia lyase, tyrosine ammonia lyase, and cinnamyl alcohol dehydrogenase in maize stalk. Crop Sci. 33:1264-1268.

Poehlman, J.M. 1979. p. 51-53. Breeding field crops. 2nd edition. AVI Publishing Company, Inc., Westport, Conn.

Rechenthin, C.A. 1951. Range grasses in the southwest; eastern gamagrass, Texas cupgrass, Pan American balsomscale and smooth cordgrass. Cattleman. 38:110-112.

SAS Institute. 1985. SAS user's guide: Statistics. 5th ed. SAS Institute, Cary, N.C.
Saunders, J.A., and J.W. McClure. 1974. The suitability of a quantitative spectrophotometric assay for phenylalanine ammonia-lyase in barley, buckwheat, and pea seedlings. Plant Physiol. 54: 412-413

Simon, U. and B.H. Park. 1983. A descriptive scheme for the stages of development in perennial forage grasses. p. 416-418. In: J. Allan Smith and V.W. Hays (ed.). Proc. 14th Int. Grassl. Congr. Lexington, KY. 15-24 June 1981. Westview Press, Boulder, Colo.

Sims, P.L. 1985. Using improved pastures to complement native range. p. 218-225. In: Proc. Intn. Ranchers Roundup. Laredo, TX, Texas Agr. Ext. Serv., College Station, Tex.

Smith, D. and C.J. Nelson. 1985. Physiological considerations in forage management. p. 326-337. In: M.E. Heath, R.F Barnes, and D.S. Metcalfe (ed.). Forges: The science of grassland agriculture. 4th ed., Iowa State Univ. Press, Ames, Ia.

Ugherughe, P.O. 1986. Relationship between digestibility of Bromus inermis plant parts. J. Agron. Crop Sci. (Berlin) 157:136-143.

Van Soest P.J., and J.B. Robertson. 1980. Systems of analysis for evaluating fibrous feeds. p. 49-60. In: W.J. Pigden. C.C. Balch CC, and M. Graham (ed.). Proc. Int. Workshop on Standardization Anal. Methodology Feeds. Ottawa, Canada. 12-14 Mar. 1979. Unipub, N.Y.

Vogel, K.P., C.L. Dewald, H.J. Gorz, and F.A. Haskins. 1985. Improvements of switchgrass, indiangrass, and eastern gamagrass-current status and future. p. 159-170. In: Proc. 38th Annual Soc. for Range Manage. Meeting. Soc. Range Manage., Denver, Colo.

Wagner G.J., and G. Hrazdina. 1984. Endoplasmic reticulum as a site of phenylpropanoid and flavonoid metabolism in Hippeastrum. Plant Physiol. 74: 901-906

Wilkes, H.G. 1972. Maize and its wild relatives. Science. 177:1071-1077.

Wright, L.S., C.M. Taliaferro, and F.P. Horn. 1983. Variability of morphological and agronomic traits in eastern gamagrass accessions. Crop Sci. 23:135-138. 